\title{
Pengembangan E-learning berbasis Technology Acceptance Model
}

\author{
(Studi kasus: Bahasa Inggris)
}

\author{
Daniel Kasse \\ Magister Teknologi Informasi \\ Universitas Gadjah Mada
}

\author{
Ir. P. Insap Santosa, M. Sc., Ph. D. \\ Staf Pengajar \\ Program S2 Teknik Elektro, \\ Fakultas Teknik, \\ Universitas Gadjah Mada
}

\author{
Dr. Ridi Ferdiana, S.T., M.T. \\ Staf pengajar \\ Program S2 Teknik Elektro, \\ Fakultas Teknik, \\ Universitas Gadjah Mada
}

\begin{abstract}
Abstrak- Banyak murid yang mengeluh karna merasa tidak cocok dengan gaya mengajar dari guru. Terjadi penolakan dalam diri mereka sehingga menjadi malas, bosan dan stress. Selama ini masih digunakan video tutorial dan power point untuk belajar. Tetapi masih kurang interaktif. Kekurangan dari penggunaan video dan slide presentasi bisa dilengkapi dengan penggunaan website untuk pembelajaran. Website yang dinamis dan kemudahan pencarian informasi sangat diperlukan untuk mendukung kegiatan belajar. Tujuan utama dari penelitian ini adalah membuat sebuah website yang memberikan layanan belajar dengan penyajian materi sesuai kebutuhan siswa.
\end{abstract}

Kata kunci-TAM, e- learning, belajar.

\section{PENDAHULUAN}

Penelitian-penelitian yang telah dilakukan dalam hal penggunaan e-learning sebagai alat bantu belajar menunjukan bahwa $e$-learning dapat membantu siswa dalam belajar. Tetapi terdapat beberapa kekurangan dalam hal penyajian materi dan pengolahan informasi. Kebanyakan e-learning yang sudah ada hanya berfungsi sebagai gudang materi dengan menampilkan materi pada halaman web ataupun berisi file-file PDF, DOC. Tidak semua e-learning menarik untuk digunakan sekalipun ada manfaatnya. Kebiasaan siswa dalam menggunakan $e$ learning untuk belajar yaitu mencari contoh soal dan penyelesaian, definisi dari istilah-istilah tertentu dan materi yang lebih lengkap. Kemudahan penggunan, dan manfaat yang dirasakan secara nyata oleh pengguna menjadi beberapa faktor yang mempengaruhi sebuah e-learning digunakan atau tidak.

Beberapa masalah yang sering dihadapi adalah kurangnya dasar pengetahuan siswa, siswa malas membaca, belajar yang tidak sesuai minat, dan kurang akan buku referensi pendukung. Inovasi e-learning memberikan kemungkinan baru untuk mengubah proses pengajaran dan pembelajaran [1]. Penggunaan video dan slide presentasi memang baik untuk memberikan informasi atau materi. Tetapi tidak cukup baik untuk berinteraksi. Kekurangan dari penggunaan video dan powerpoint bisa dilengkapi dengan penggunaan website untuk pembelajaran. Alat belajar berbasis web dinamis sangat diperlukan dalam pengajaran modern, mengingat kemampuan untuk interaksi sesuai kebutuhan sebagai sarana merangsang dan melibatkan siswa [2]. Hasil dari penelitian ini dapat digunakan sebagai alat bantu belajar, membuat pengguna lebih baik lagi dalam belajar, memperkaya gaya belajar murid dan untuk pengembangan e-learning selanjutnya.

\section{TINJAUAN PUSTAKA}

Penelitian ini berfokus pada penyajian materi yang sesuai kebutuhan siswa berdasarkan konsep technology acceptance model (TAM). Teori-teori dan konsep terkait sebagai berikut :

\section{A. e-learning}

E-learning sering disebut penggunaan jaringan informasi dan e-learning komunikasi dalam proses belajar mengajar. Sejumlah istilah lain juga digunakan untuk menggambarkan model dari mengajar dan belajar. termasuk belajar online, belajar virtual, pembelajaran terdistribusi, jaringan dan pembelajaran berbasis web. Pada dasarnya, semua mengacu pada proses pendidikan yang memanfaatkan e-learning informasi dan komunikasi untuk menengahi asynchronous serta pembelajaran sinkron dan kegiatan mengajar.

Sebuah atribut kunci dari informasi dan e-learning komunikasi adalah kemampuannya untuk memungkinkan akses yang fleksibel ke informasi dan sumber daya. Akses yang fleksibel mengacu pada akses dan penggunaan informasi dan sumber daya pada waktu, tempat dan kecepatan yang cocok dan nyaman untuk pelajar individu daripada guru atau organisasi pendidikan. 
E-learning semakin populer di semua bidang dan jenjang pendidikan dan pelatihan. Atribut kritis e-learning meliputi fleksibilitas waktu, tempat dan kecepatan belajar. E-learning memberi kesempatan untuk merancang lingkungan belajar yang otentik, terletak dalam konteks pembelajaran, dan juga dalam rangka untuk memberikan siswa pengalaman "learning by doing" berbasis masalah [3].

\section{B. Belajar}

Belajar adalah suatu proses aktif, proses mereaksi terhadap semua situasi yang ada pada siswa. Belajar merupakan suatu proses yang terarah pada sebuah tujuan [4].

Belajar bukan hanya sekedar mengetahui "apa" tetapi juga mengetahui "bagaimana" dan segala sesuatu yang berhubungan. Ketika mempelajari sesuatu sebagian orang lebih suka membangun informasi langkah demi langkah yang lambat. Orang-orang jenis ini disebut pembelajar "linear". Sebagian orang lebih suka atau perlu melihat "gambaran keseluruhan". Orang-orang seperti ini disebut pembelajar "global".

Pendekatan yang sepenuhnya "linear" adalah dengan mengamati rambut, kening, alis, mata, hidung, mulut, dan dagu seseorang. Inilah pembangunan informasi pembangunan informasi berurut, langkah demi langkah, dan lambat. Untuk yang pembelajar global akan langsung memperhatikan pola untuk mengenali seseorang. Manusia mengingat hal-hal mudah yang memiliki asosiasi yang kuat - itulah sebabnya pengiklan TV menggunakan gambar visual yang kuat, menggunakan musik dan irama, dan berusaha untuk melibatkan emosi kita. Ini adalah alasan mengapa manusia dapat mengingat kata-kata dari sebuah lagu pop dengan sedikit usaha atau tidak sadar, namun perlu usaha untuk mengingat daftar tanggal sejarah. Jika mempelajari teknik-teknik belajar yang paling cocok dengan gaya belajar yang disukai, maka belajar dalam cara yang paling alami. Karena belajar terasa alami (ramah otak), belajarpun terassa lebih mudah. Karena lebih mudah, belajarpun menjadi lebih cepat. [5].

Kemampuan belajar dengan cepat, membuat keputusan yang baik, dan berpikir kreatif adalah beberapa ketrampilan penting yang dibutuhkan. Informasi yang ada, tidak semua bermanfaat. Laju informasi yang semakin cepat dan dibutuhkan pengetahuan tentang cara menyerap informasi lebih cepat juga. Dari analisis tentang otak, disimpulkan bahwa pembelajar aktif melibatkan enam tahap. Enam tahap ini dapat disimpulkan oleh akronim K-U-A-S-A-I (atau M.A.S.T.E.R. yang diciptakan oleh pelatih Accelarated learning, Jayne Nicholl), yaitu:
1. Kerangka pikiran untuk sukses

Pelajar diarahkan untuk berada dalam kerangka pikiran yang kaya. Kerangka pikiran harus santai, yakin, dan termotivasi.

2. Penguraian fakta

Fakta harus dilibatkan untuk disesuaikan dengan gaya belajar yang disukai pengguna. Kebutuhan setiap orang untuk mendengar, melihat, atau terlibat secara fisik dalam hal yang sedang dipelajari berbeda-beda.

3. Menelusuri makna

Pelajar akan dibimbing untuk menelusuri apa yang sedang dipelajari. Menjelajahi suatu topik sepenuhnya, akan mengubah pengetahuan yang dangkal menjadi pemahaman yang mendalam.

4. Menyentakan ingatan

Memperhatikan unsur-unsur kunci yang dipelajari. Tujuanya adalah menyimpan satu atau dua fakta kunci dalam ingatan, supaya sisa pelajaran dapat membanjir masuk kembali.

5. Mengajukan yang diketahui

Menunjukan kalau sudah benar-benar tahu apa yang dipelajari.

6. Introspeksi

Bertujuan meningkatkan tak hanya apa yang diketahui, tetapi juga cara belajar. Dengan demikian semakin lama semakin lebih baik [5].

\section{Technology Acceptance Model (TAM)}

TAM merupakan adaptasi dari Theory of Reasoned Action (TRA) untuk bidang Sistem Informasi. TAM berpendapat bahwa manfaat yang dirasakan dan persepsi kemudahan penggunaan menentukan niat individu untuk menggunakan sistem dengan niat untuk menggunakan melayani sebagai mediator penggunaan sistem yang sebenarnya. Dirasakan manfaat juga dilihat sebagai secara langsung dipengaruhi oleh persepsi kemudahan penggunaan. Para peneliti telah menyederhanakan TAM dengan menghapus konstruksi sikap dari TRA pada spesifikasi saat ini [6]. Upaya untuk memperluas TAM umumnya diambil salah satu dari tiga pendekatan: memperkenalkan faktor dari model terkait, memperkenalkan faktor kepercayaan tambahan atau alternatif, dan penghubung antara manfaat yang dirasakan dengan persepsi kemudahan penggunaan [7]. 


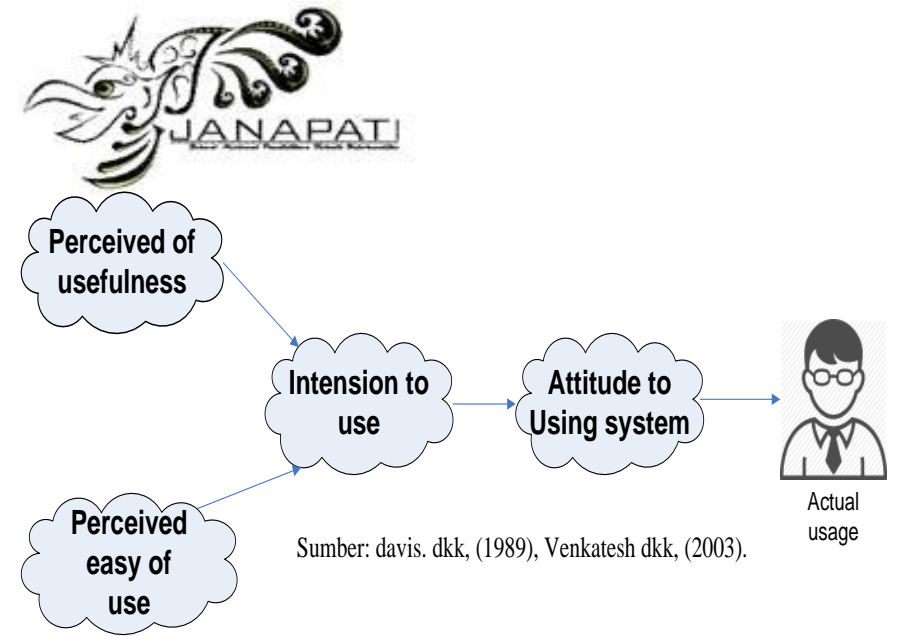

Gambar 1. Technology Accetance Model

1. Persepsi kemudahan penggunaan (perceived ease of use), didefinisikan sebagai ukuran kepercayaan seorang menggunakan suatu e-learning, terbebas dari usaha.

2. Persepsi kegunaan (perceived usefulness), didefinisikan sebagai ukuran kepercayaan seorang menggunakan suatu e-learning, akan membantu proses belajar.

3. Sikap terhadap penggunaan e-learning (attitude toward using), didefinisikan sebagai evaluasi dari pengguna tentang ketertarikannya dalam menggunakan e-learning .

4. Minat perilaku menggunakan e-learning (behavioral intention to use), didefinisikan sebagai minat (keinginan) seseorang untuk melakukan perilaku tertentu.

5. Penggunaan e-learning (actual technology usage), diukur dengan jumlah waktu yang digunakan untuk berinteraksi dengan e-learning dan frekuensi penggunaan e-learning tersebut. [8].

\section{Antarmuka Pengguna}

Donald Norman memperkenalkan beberapa prinsipprinsip desain antarmuka pengguna. Dasar dan konsep yang sekarang dianggap penting untuk memahami mengapa beberapa desain yang lebih bermanfaat dan dapat dipelajari daripada yang lain, yaitu:

- Visibilitas - Fungsi yang lebih terlihat, pengguna lebih mungkin akan dapat mengetahui apa yang harus dilakukan selanjutnya. Incontrast, ketika fungsi yang "tak terlihat" itu membuat pengguna lebih sulit untuk menemukan dan tahu bagaimana menggunakannya.

- Umpan balik - Umpan balik adalah tentang mengirim kembali informasi tentang tindakan apa yang telah dilakukan dan apa yang telah dicapai, yang
ISSN 2089-8673

Jurnal Nasional Pendidikan Teknik Informatika (JANAPATI)

Volume 3, Nomor 3, Desember 2014

memungkinkan seseorang untuk melanjutkan kegiatan tersebut.

- Batasan - Konsep desain yang menjadi kendala mengacu menentukan cara membatasi jenis interaksi pengguna yang dapat terjadi pada saat tertentu.

- Pemetaan - ini mengacu pada hubungan antara kontrol dan efek pengguna di dunia. Sebuah contoh dari pemetaan yang baik antara kontrol dan efek adalah panah atas dan bawah digunakan untuk mewakili atas dan ke bawah gerakan kursor, masing-masing, pada keyboard komputer.

- Konsistensi - ini mengacu pada merancang antarmuka untuk memiliki operasi yang sama dan menggunakan unsur-unsur yang sama untuk mencapai tugas-tugas serupa. Secara khusus, antarmuka yang konsisten adalah salah satu yang mengikuti aturan, seperti menggunakan operasi yang sama untuk memilih semua objek. Sebagai contoh, sebuah operasi yang konsisten menggunakan tindakan input yang sama untuk menyorot objek grafis pada antarmuka, seperti selalu mengklik tombol kiri mouse.

- Affordance - adalah istilah yang digunakan untuk merujuk kepada atribut dari sebuah benda yang memungkinkan orang untuk tahu bagaimana menggunakannya. Misalnya, tombol mouse untuk "klik". Pada tingkat yang sangat sederhana, berarti "untuk memberikan petunjuk". Ketika affordances perseptual fisik benda jelas, mudah untuk mengetahui bagaimana berinteraksi dengan sesuatu.[9].

\section{PENYAJIAN MATERI}

Ketika menggunakan sebuah e-learning siswa lebih cenderung mencari contoh soal-penyelesaian daripada isi materi yang lengkap, dan mencari istilah atau arti kata yang belum dipahami. Berdasarkan hal-hal tersebut maka struktur dan perancangan antarmuka dari e-learning seperti berikut: 
ISSN 2089-8673

Jurnal Nasional Pendidikan Teknik Informatika (JANAPATI)

Volume 3, Nomor 3, Desember 2014

A. Struktur penyajian materi

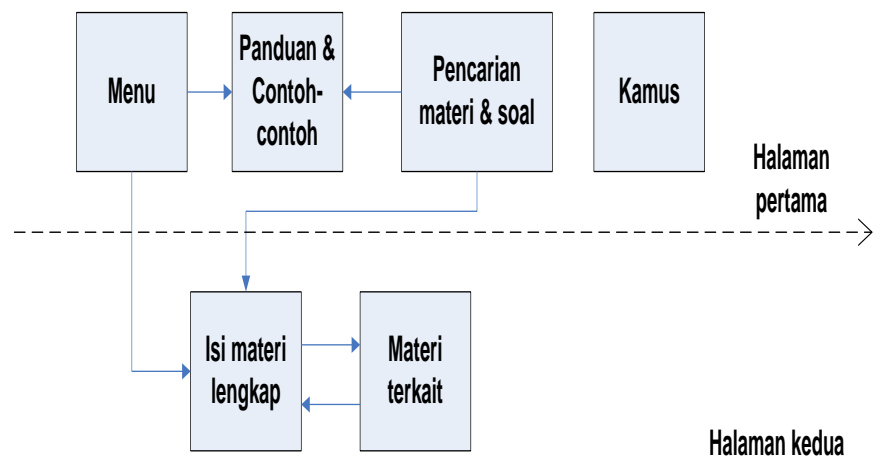

Gambar 2. Struktur penyajian materi

\section{B. Perancangan antarmuka}

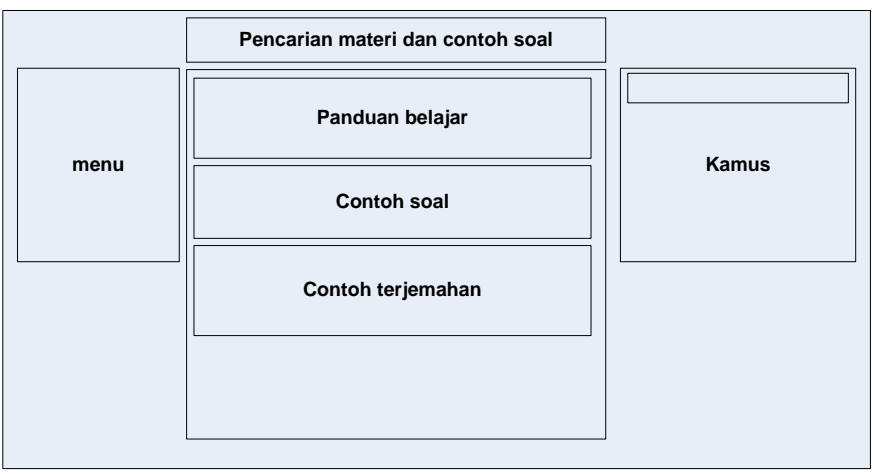

Gambar 3. Halaman pertama

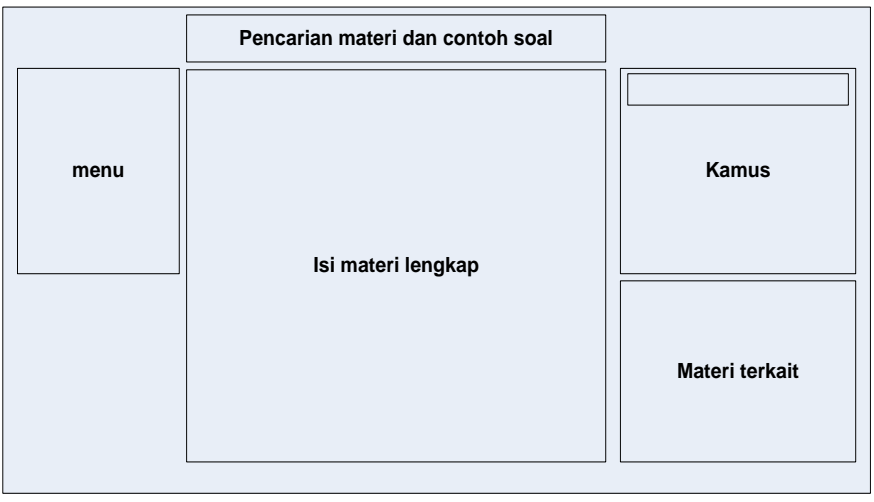

Gambar 4. Halaman kedua

\section{HIPOTESIS}

Hipotesis penelitian ini adalah:

- Penyajian panduan belajar, contoh soal, dan contoh terjemahan pada halaman depan dari e-learning akan lebih menambah minat penggunaan e-learning.
- Kemudahan mencari materi dari e-learning akan menjaga minat penggunaan $e$-learning.

\section{METODE PENELITIAN}

Pada penelitian ini akan dilakukan eksperimen dan survey. Skenario untuk penelitian ini sebagai berikut:

1. Presentasi pennggunaan e-learning

2. Pengujian e-learning

3. Pengisian kuestioner

4. Perbaikan e-learning

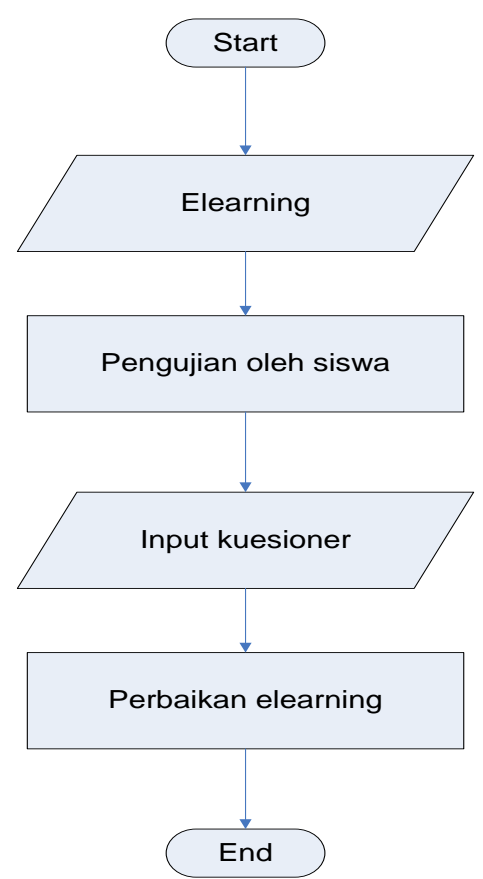

Gambar 5. Skenarion penelitian

Bahan untuk e-learning yang digunakan adalah materi pelajaran Bahasa Inggris yang diambil dari :

- $\quad$ www.wordsmile.com

- Toefl text books.

Responden untuk penelitian ini berjumlah 180 siswa. Berasal dari 2 sekolah yaitu SMAK Giovani Kupang dan SMAK Mercusuar Kupang.

\section{KESIMPULAN}

Penelitian ini sedang dalam proses pembuatan elearning. Hasil dari penelitian ini dapat digunakan sebagai dasar untuk pengembangan website, sebagai petunjuk untuk komputasi 
yang lebih lanjut dan penyajian materi yang lebih user friendly, dan melakukan penelitian dengan studi kasus berbeda untuk mata pelajaran yang lain.

\section{Daftar Pustaka:}

[1]. Sessoms, D. (2008). Interactive instruction: Creating interactive learning environments through tomorrow's teachers. International Journal of Technology in Teaching and Learning, 4(2), 86-96.

[2]. Preece, J., Rogers, Y., Sharp, H. (2002), Interaction Design: Beyond Human-Computer Interaction, New York: Wiley, p.21.

[3]. Naidu Som,(2006). E-learning, A Guidebook of Principles, Procedures and Practices.

[4]. Khairani, M. (2013). Psikologi Belajar. Aswaja Pressindo.

[5]. Rose, Colin. (2002). Accelerated Learning. Kaifa.

[6]. Venkatesh, V., Morris, M. G., Davis, G. B., \& Davis, F. D. (2003). User acceptance of information technology: Toward a unified view. MIS Quarterly, 27(3), 425-478.

[7]. Wixom, B. H., \& Todd, P. A. (2005). A theoretical integration of user satisfaction and technology acceptance. Information Systems Research, 16(1), 85-102.

[8]. Davis, F. D. (1989). Perceived usefulness, perceived ease of use, and user acceptance of information technology. MIS Quarterly, 13(3), 319339.

[9]. Norman, D. (2002). The Design Of Everyday Things. Basic Books. 